\title{
CONGENITAL LOBAR EMPHYSEMA WITH CYSTIC LUNG ABNORMALITY: ANTENATAL ULTRASOUND APPEARANCE
}

\author{
Youn Jeong Lee, MD, Hyun Chul Jeong, MD, Heui Jin Joo, MD, Gwang Jun Kim, MD \\ Department of Obstetrics and Gynecology, Chung-Ang University Hospital, Chung-Ang University College of Medicine, Seoul, Korea
}

A 33-year-old woman at $23^{+2}$ weeks of gestational age was referred for consultation due to the findings of a cyst in the right lung of the fetus. Prenatal ultrasound showed a $3 \mathrm{~cm}$-sized hypoechogenic cyst, suggesting congenital cystic adenomatoid malformation. As the cyst grew and compressed the heart, serial cyst aspirations were performed. The cyst was proved to be congenital lobar emphysema on postnatal histopathologic exam. No other anomaly was found. Only few cases of congenital lobar emphysema (CLE) have been reported up to date and the prenatal diagnosis is extremely rare. Typically, fetal sonographic features of CLE have a bright echogenic lung and, to date, only 3 cases have been reported to have a cystic lesion. We report a case of a fetus with a cystic lung abnormality and postnatally proved congenital lobar emphysema.

Keywords: Congenital lobar emphysema; Prenatal diagnosis; Ultrasound; Lung

The routine use of prenatal sonography has made early identification and serial evaluation of congenital lung lesions possible [1]. The antenatal diagnosis of lung abnormalities characterized by cyst formation or increased echogenicity include congenital cystic adenomatoid malformation (CCAM), pulmonary sequestration (PS), bronchogenic cysts and congenital lobar emphysema. These fetuses have a congenital echogenic mass, including a mediastinal shift and displacement of the heart, resulting in compression of the contralateral lung [2]. In some cases, there is acute respiratory distress after birth, requiring the standard treatment of surgical removal of the affected area [3]. In order to improve prognosis in perinatal care, it differentiated diagnosis of lung abnormalities is necessary. Congenital lobar emphysema (CLE) is a rare developmental anomaly of the lung, characterized by air trapping and overdistension of segments and lobes $[4,5]$. Prenatal diagnosis of CLE has been rarely reported in the literature and only histology later can confirm the presence of CLE $[4,6]$.

\section{Case Report}

A 33-year-old, gravid 3, para 1 woman was referred to our unit at $23^{+2}$ weeks of gestation presenting with a cyst in the lung of the fetus. She had no past medical history, no operation history, and had not taken any kind of medication, except for oral iron for the current pregnancy. Her family did not have any history of medical illnesses, and she did not smoke nor drink. She had one full-term vaginal delivery two years prior. At the beginning of the current pregnancy, the patient did not have any obstetrical problems. Mid-gestation screening was reported low risk. A $1.8 \mathrm{~cm}$-sized hypoechogenic single cyst in the right lower lobe was detected on ultrasound examination at $21^{+2}$ weeks of gestation and was increased to $2.8 \mathrm{~cm}$-size until 23 weeks of gestation. Therefore, she was referred to our hospital at $23^{+2}$ weeks of gestation due to a cyst increased in sized in the lung of the fetus.

Sonographs revealed a $3 \mathrm{~cm}$-sized hypoechogenic single cyst in the right lower lobe. Displacement of the heart and mediastinum

Received: 2012.4.16. Revised: 2012.6.28. Accepted: 2012.9.13.

Corresponding author: Gwang Jun Kim, MD

Department of Obstetrics and Gynecology, Chung-Ang University Hospital, Chung-Ang University College of Medicine, 102 Heukseok-ro, Dongjak-gu, Seoul 156-755, Korea Tel: +82-2-6299-1648 Fax: +82-2-6263-2187

E-mail: gjkim@cau.ac.kr

This is an Open Access article distributed under the terms of the Creative Commons Attribution Non-Commercial License (http://creativecommons.org/licenses/ by-nc/3.0/) which permits unrestricted non-commercial use, distribution, and reproduction in any medium, provided the original work is properly cited.

Copyright (c) 2012. Korean Society of Obstetrics and Gynecology 


\section{KOREAN JOURNAL OF OBSTETRICS \& GYNECOLOGY}

Youn Jeong Lee, et al. CLE with cystic lung abnormality
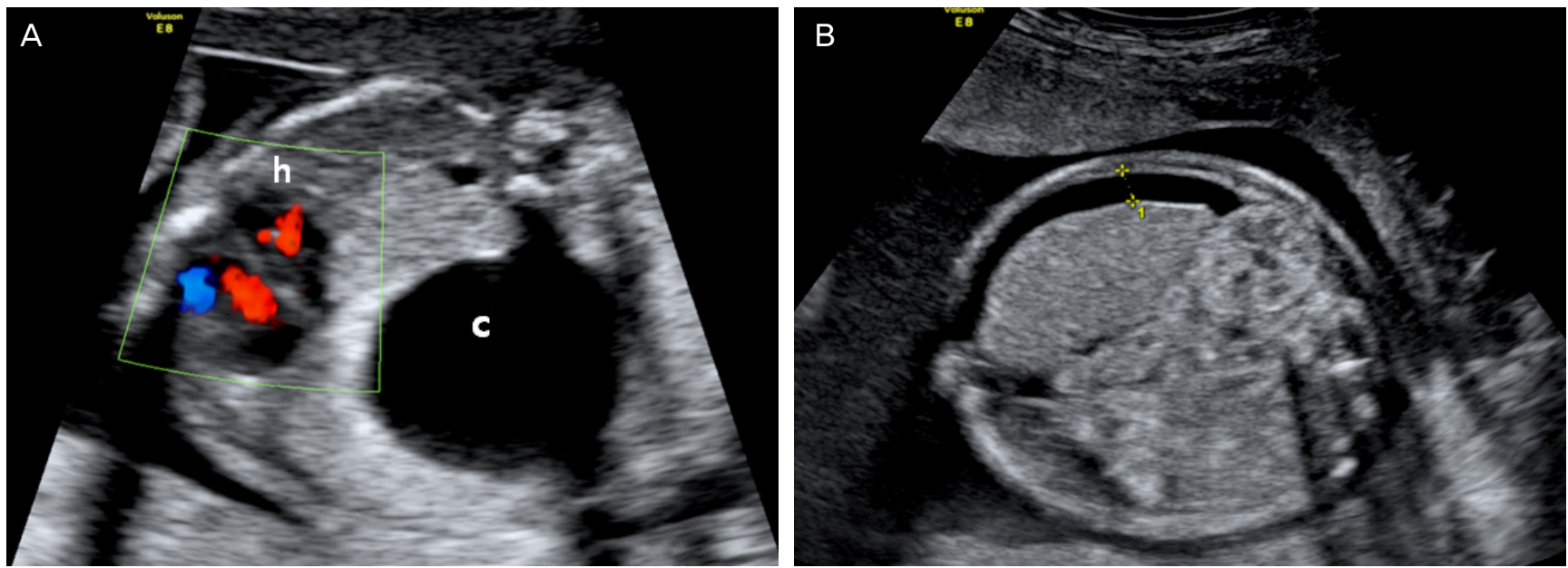

Fig. 1. Cross section view of the thorax. (A) The displacement of the heart and mediastinum to the left and compression of the heart (h) due to cyst (c) in the right lower lobe. (B) Ascite is shown in the abdomen.
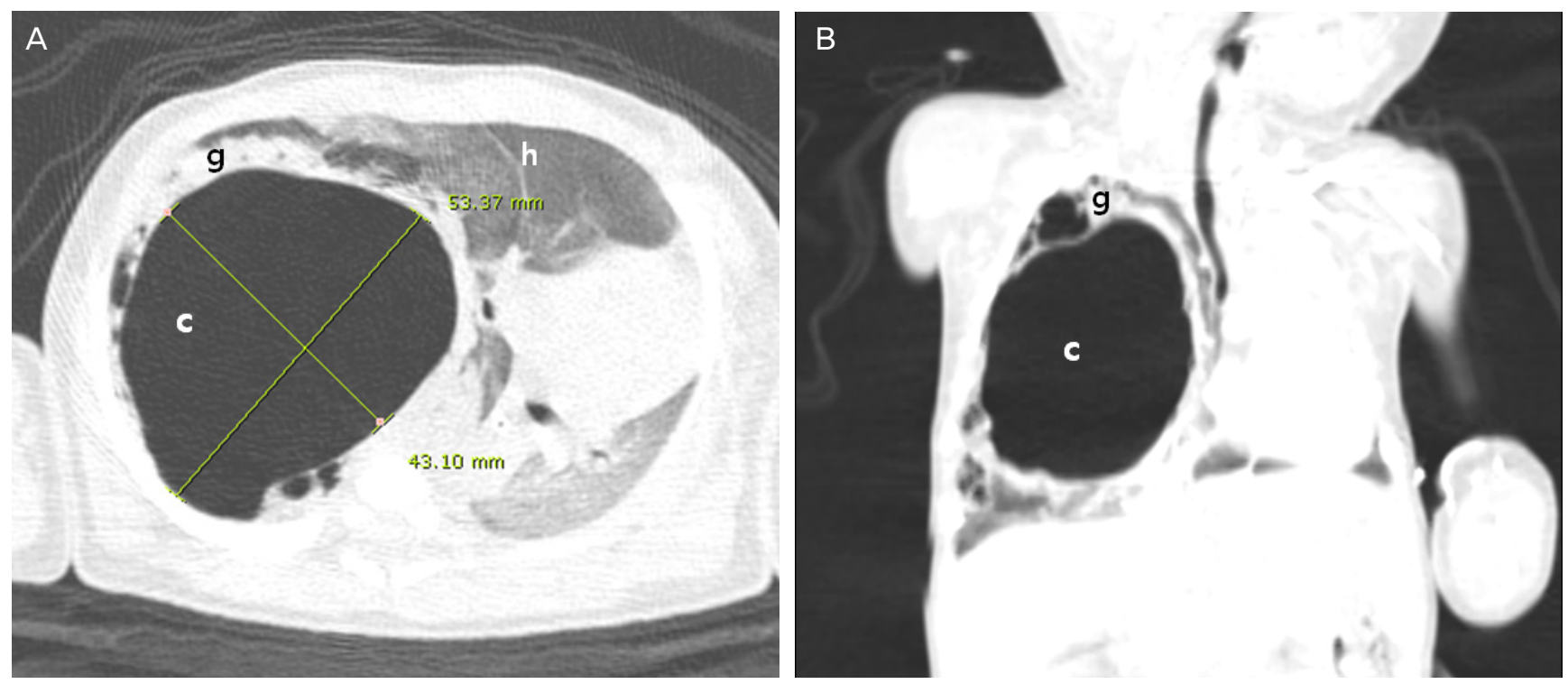

Fig. 2. Postnatal chest computed tomography. The hypoinflated right lung (h) with inner large cyst (c) and mediastinal shift were seen. Ground glass opacity (g) suggest atelectasis. (A) Cross section view. (B) Coronal view.

to the left and compression of the heart were seen with normal Doppler images of the umbilical cord and the ductus venosus (Fig. 1A). The patient underwent amniocentesis, and a normal karyotype was detected and no other fetal abnormality was observed. On the basis of the detection of a large and predominant cystlike mass, our tentative prenatal diagnosis was CCAM (type I) [7]. The patient was counseled regarding the etiologies considered and prognosis and informed to the symptoms of polyhydramnios. The mass was followed by serial sonographic examination to determine its rate of growth as well as to detect early signs of fetal problems. There were signs of fetal hydrops on the first visit but no exacerbation was observed on the weekly follow-ups (Fig. 1B). The patient underwent amnioreduction procedure to treat polyhydramnios found at $25^{+2}$ weeks of gestation, but amniotic fluid volume continued to rather increase until $32^{+2}$ weeks of gestation. Subsequent amnioreductions were performed weekly for polyhydramniOs, and then amniotic fluid level was normalized. At $25^{+2}$ weeks of gestation, the size of the cyst increased to $4.4 \mathrm{~cm}$. Nearly $30 \mathrm{~mL}$ of cystic fluid was aspirated to reduce its size to $2.8 \mathrm{~cm}$, but the cyst recurred to increase in size again to $4.3 \mathrm{~cm}$ on the following week. A total of 6 cyst aspirations were performed by $32^{+2}$ weeks of gestation. The $4.7 \mathrm{~cm}$-sized hypoechogenic single cyst did not 
increase in size and was observed until delivery.

At $38^{+5}$ weeks' gestation, the mother had a Cesarean delivery to ensure effective care immediately after birth. The 2,792-g male neonate had Apgar scores of 8 and 9 at 1 and 5 minutes, respectively. The baby was admitted to the neonatal intensive care unit for observation. There were no signs of respiratory distress and his neonatal course was uneventful. A chest radiograph showed a huge cystic lesion in the right hemithorax with displaced mediastinal structures such as movement of the heart to left side and atelectatic change of the left lung which was compatible with the prenatal diagnosis of CCAM (type I). A computed tomography (CT) scan on 2 day showed multiple variable sized cystic lesions. The largest was $5.5 \mathrm{~cm}$ in diameter, located in the right lung and ground glass opacity in the remaning lungs, suggesting atelectasis (Fig. 2). He had respiratory distress 2 days after birth and was tachypneic without cyanosis. At 3 days of age, a thoracotomy with right lower lobe lobectomy was performed. Biopsy confirmed the diagnosis of CLE with hemorrhage and mild inflammation. Postoperatively the baby developed a left pneumothorax which required drainage. Thereafter, recovery was excellent and the baby was discharged at 4 weeks of age.

\section{Discussion}

Congenital lobar emphysema is a rare congenital pulmonary anomaly characterized by air trapping within one or more of the pulmonary lobes with secondary overdistension leading to compression of the remaining lobes and mediastinal shift [1]. The incidence is 1 per 20,000 to 30,000 deliveries, whereas the incidence in utero is unknown [4]. The pathophysiology of CLE consists of disruptions of brochopulmonary development resulting in intrinsic obstruction of bronchus [4]. Intrinsic obstruction involves dysplastic bronchial cartilage or endobronchial lesion with blockage due to mucosal fold, septa, or mucosal plugs [6]. Diffuse bronchial inflammation secondary to congenital cytomegalovirus infection has been reported as a cause of CLE [8]. However, the exact cause of CLE is difficult to determine, and a definitive cause cannot be identified in approximately $50 \%$ of cause [6].

Antenatal imaging with sonography has resulted in early identification and serial evaluation of congenital lung lesions. The antenatal diagnosis of lung abnormalities characterized by cyst formation or increased echogenicity include CCAM, pulmonary sequestration, bronchogenic cysts, and, less commonly, congenital lobar emphysema. With CCAM, sonography shows a large cyst (3 to $10 \mathrm{~mm}$ in diameter, type I), multiple cyst $(0.5$ to $2.0 \mathrm{~cm}$ in diameter, type II), and the small cystic or solid mass (type III), usually involving one lobe of the lungs [9]. The natural history of fetal CCAMs is variable but most cases of prenatally diagnosed CCAM have good outcome. Prenatal treatment can considered by means of cyst aspiration or thoraco-amniotic shunting and these procedure should be considered before 32 to 33 weeks of gestation. Pulmonary sequestration appears, as a well-defined, solid, and triangular mass and is supplied by an anomalous systemic artery that is usually situated in the lower lobes [10]. The natural history of pulmonary sequestration depends on where they are located, however a considerable number of pulmonary sequestration lesions regress dramatically before birth. Bronchogenic cysts may present as single or, less commonly, as multiple lesions. Their dimensions vary from a few millimeters to greater than $5 \mathrm{~cm}$ [11]. For its prognosis and treatment may vary, differential diagnosis is hence needed to diagnose the specific disease in a patient. Prenatal diagnosis of CLE is rarely reported in the literature, because the fetal sonographic features of CLE have not been well described and its prevalence in utero is low. Therefore, in most cases, the diagnosis of CCAM will be suspected, but the correct diagnosis of CLE can only be made postnatally on the basis of histology. Often CLE, CCAM, PS, and bronchogenic cysts are described as one clinical group representing a spectrum of the same disease [12].

Mostly, fetal sonographic features of CLE have a bright echogenic

Table 1. Summary of findings in neonates

\begin{tabular}{|c|c|c|c|c|c|c|c|c|}
\hline Author & Year & $\begin{array}{l}\text { Sonographic } \\
\text { diagnosis }\end{array}$ & Week & Sonographic feature & $\begin{array}{l}\text { Respiratory } \\
\text { distress }\end{array}$ & Treatment & $\begin{array}{l}\text { Histologic } \\
\text { diagnosis }\end{array}$ & Outcome \\
\hline Okabe et al. [13] & 1992 & CCAM & $\mathrm{N} / \mathrm{A}$ & Cystic lesion, right middle & Yes & Surgery & CLE & $\mathrm{N} / \mathrm{A}$ \\
\hline Babu et al. [6] & 2000 & CCAM & 22 & $\begin{array}{l}\text { Microcystic; macrocystic, right } \\
\text { upper and middle }\end{array}$ & No & Surgery & CLE & Good \\
\hline Ankermann et al. [5] & 2004 & CCAM & 20 & Microcystic left upper & No & Surgery & CLE & Good \\
\hline Present & 2011 & CCAM & 21 & Macrocystic right lower & Yes & Surgery & CLE & Good \\
\hline
\end{tabular}

Wk, weeks' gestation at diagnosis; CCAM, congenital cystic adenomatoid malformation; N/A, not available; CLE, congenital lobar emphysema. 


\section{KOREAN JOURNAL OF OBSTETRICS \& GYNECOLOGY}

Youn Jeong Lee, et al. CLE with cystic lung abnormality

lung without abnormal blood flow. This increased echogenicity is thought to result from excessive lung fluid in the alveoli, and negative intra-thoracic pressure postnatally that results in airway collapse and air trapping leading to the manifestation of CLE $[4,6]$. Thus far, 3 cases of cystic lesions have been reported (Table 1) $[5,6,13]$. Antenatal imaging with sonography has shown polyhydramnios and fetal hydrops due to disturbed fetal circulation and impaired swallowing. There may also be a mediastinal shift, leading to fetal impairment. All the lesions mentioned above are predictors of severe respiratory distress or poor outcomes [14]. The antenatal detection of fetal lung echogenicity allows pediastric follow up after birth, which makes possible early diagnosis and managemenst before the infant has symptoms.

Clinically CLE can present with acute symptoms such as tachypnea, respiratory distress, or cyanosis. Simple chest $\mathrm{X}$-ray is usually sufficient for CLE diagnosis, demonstrating lobar hyperinflation, mediastinal shfit and atelectasis of the opposite lung. However if chest radiography is not definitive, a chest $\mathrm{CT}$ can be helpful in determining the correct diagnosis. Standard treatment for acute respiratory distress is surgical resection of the affected lung area [3]. Prognosis and survival with surgery are good [15].

There are many reports of spontaneous regression of pulmonary sequestration and CCAM, similar to these lesions, CLE can decrease in size during pregnancy [5]. Therefore, even when they appear to have disappeared, continuing follow-up of prenatal sonographic abnormalities is required.

The prenatal diagnosis of CLE is very rare and the fetal sonographic features of CLE have not been well described. Typically, fetal sonographic features of CLE show a bright echogenic lung and, thus far, only 3 cases have been reported to have cystic lesion. This case reports that CLE should be included in the differential diagnosis of an antenatally detected hypoechoic cystic lung apart from CCAM and pulmonary sequestration.

\section{References}

1. Kravitz RM. Congenital malformations of the lung. Pediatr Clin North Am 1994;41:453-72.

2. Richards DS, Langham MR Jr, Dolson LH. Antenatal presentation of a child with congenital lobar emphysema. J Ultrasound Med 1992;11:165-8.

3. Clements BS. Congenital malformations of the lungs and air- ways. In: Taussig LM, Landau LI, editors. Pediatric respirology medicine. St Louis (MO): Mosby; 1999. p.1106-36.

4. Pariente G, Aviram M, Landau D, Hershkovitz R. Prenatal diagnosis of congenital lobar emphysema: case report and review of the literature. J Ultrasound Med 2009;28:1081-4.

5. Ankermann T, Oppermann HC, Engler S, Leuschner I, Von Kaisenberg CS. Congenital masses of the lung, cystic adenomatoid malformation versus congenital lobar emphysema: prenatal diagnosis and implications for postnatal treatment. J Ultrasound Med 2004;23:1379-84.

6. Babu R, Kyle P, Spicer RD. Prenatal sonographic features of congenital lobar emphysema. Fetal Diagn Ther 2001;16:2002.

7. Stocker JT, Madewell JE, Drake RM. Congenital cystic adenomatoid malformation of the lung. Classification and morphologic spectrum. Hum Pathol 1977;8:155-71.

8. Carrol ED, Campbell ME, Shaw BN, Pilling DW. Congenital lobar emphysema in congenital cytomegalovirus infection. Pediatr Radiol 1996;26:900-2.

9. Stocker JT. Cystic lung disease in infants and children. Fetal Pediatr Pathol 2009;28:155-84.

10. Goldstein RB. Ultrasound evaluation of the fetal thorax. In: Callen PW, editor. Ultrasonography in obstetrics and gynecology. 4th ed. Philadelphia (PA): Saunders; 2000. p.426-55.

11. Bagolan P, Bilancioni E, Nahom A, Trucchi A, Inserra A, Neri M, et al. Prenatal diagnosis of a bronchogenic cyst in an unusual site. Ultrasound Obstet Gynecol 2000;15:66-8.

12. Buntain WL, Isaacs H Jr, Payne VC Jr, Lindesmith GG, Rosenkrantz JG. Lobar emphysema, cystic adenomaloid malformation, pulmonary sequestration, and bronchogenic cyst in infancy and childhood: a clinical group. J Pediatr Surg 1974;9:8593.

13. Okabe K, Hara K, Ando A, Sano S, Shimizu N, Teramoto S, et al. Congenital lobar emphysema successfully treated by right upper lobectomy at five hours after delivery: a case report. Kyobu Geka 1992;45:590-4.

14. Usui N, Kamata S, Sawai T, Kamiyama M, Okuyama H, Kubota A, et al. Outcome predictors for infants with cystic lung disease. J Pediatr Surg 2004;39:603-6.

15. Al-Bassam A, Al-Rabeeah A, Al-Nassar S, Al-Mobaireek K, AlRawaf $A$, Banjer $H$, et al. Congenital cystic disease of the lung in infants and children (experience with 57 cases). Eur J Pediatr Surg 1999;9:364-8. 


\section{선천성 폐기종의 산전초음파}

중앙대학교 의과대학 산부인과학교실

이윤정, 정현철, 주희진, 김광준

임신 23주 2일된 33세 산모의 태아 오른쪽 폐에 물혹이 관찰되어 전원되었다. 산전초음파상 $3 \mathrm{~cm}$ 크기의 저음영 낭종이 관찰되어 선천 성 낭성 선종양 기형(congenital cystic adenomatoid malformation)이 의심되었다. 낭종이 자라면서 심장을 압박하였기 때문에 낭종흡인을 연속적으로 시행하였다. 그 낭종은 출생 후 조직학적 검사를 통해 선천성 폐기종(congenital lobar emphysema)으로 확진되었고, 다른 동 반 기형은 관찰되지 않았다. 현재까지 선천성 폐기종은 몇 개의 경우만 보고되었고, 산전진단된 경우는 거의 없었다. 대부분의 선천성 폐 기종은 산전초음파상 밝은 음영을 나타내며 현재까지 세 경우만이 낭종의 형태로 나타났다. 저자들은 산전초음파상 낭종의 형태로 나타 났으나 출생 후 선천성 폐기종으로 확진된 1 예를 경험하였기에 간단한 문헌고찰과 함께 보고하는 바이다.

중심단어: 선천성 폐기종, 산전진단, 초음파, 폐 